\title{
To Lead Change - To Work and Study with Creativity and Structure - A Course Design for Deeper Learning Outcomes within a Course in Quality Technology
}

\author{
DOI: 1012776/QIP.V23I1.1167
}

Anette Oxenswärdh, Per-Arne Forsberg

Received: 24 September 2018 Accepted: 26 February 2019 Published: 31 March 2019

\begin{abstract}
Purpose: In this paper a new course design as a case study is presented. The course was given at bachelor level at Uppsala university, campus Gotland, within the division of quality technology. The purpose of the case is to give students an opportunity to practice acquired theoretical knowledge by offering them the opportunity to create an organization of their dreams, working in small groups.
\end{abstract}

Methodology/Approach: This paper builds upon a case study approach, combining a literature review, document studies over the performed course and evaluations over the course.

Findings: The case study shows that course design can be an important inspiration and a bridge between theory and practice for the students. Course design seems to support students' learning processes according to evaluations of the course. Course design offers benefits of the collective learning, especially for distance students. It increases independence, understanding of one's mission and accountability for it. Students are given the opportunity to practice the theoretical knowledge in their education in a creative and inspiring way. Still, there are further demands and challenges left of improvement in the course design.

Research Limitation/implication: The research limitation is that this study consists of only one course in Quality Technology.

Originality/Value of paper: This study contributes to the discussion about learning at university level through a case study.

Category: Case study

Keywords: change management; collective learning; responsibility; project management; agile methods; case study 


\section{INTRODUCTION}

The concept of change management has become one of today's most widely used and controversial concepts. It is therefore important to develop activities within university course about organizational context in order to increase students understanding of the goals for more sustainable practice (Kotter, 2012; 2014). Society and organisations change more and faster than ever, and the impact on organizations' competiveness today is greater than before. A successful organization is one that adapts to change, anticipate future needs and aim for high added value in the long term (Foley and Zahner, 2009). There is not only the product but also the organizational structure and management that have to adapt to change.

There is a lot of literature and research of different kind of about changes, as well as models for change and how changes should be conducted. However, even if active leaders say the majority of their work is connected to change management, according to Forslund (2013), managers apply change management models to a relatively small extent. Managers do not have incentives, focus and ability to apply theoretical models in practice. Hence, there is a gap between theory and practice, which could be a knowledge transfer problem which occur as one of the main obstacles to improved competitiveness (Hallencreutz, 2012). Furthermore, are many organizations only passive adapters of the changes instead of being active change managers.

Students at the universities do study different theories about change management but have limited knowledge on how to bring it into practice (Oxenswärdh, 2017; Taylor, 1999). The Department of Engineering Sciences at Uppsala University/Campus Gotland offers undergraduate courses in quality, management and organization. The courses try to meet the need to develop students' ability to work in different organizations outside university. Students are offered opportunities to develop professional skills in a collegial and mutual cooperation with different organizations. In this course, though, students created a fictive organization by themselves around some important organizational themes. In this creation the agile methods were adopted as tools to assist and structure the change and organizational development.

Any planned and directed change by individuals or collectives is built on learning. Learning can be defined more generally as the process of acquiring knowledge, skills, norms, values, or understanding through experience, imitation, observation, modelling, practice, or study; by being taught; or as a result of collaboration (Illeris, 2007). The learning process activates several other processes: processes of understanding the assignment and its responsibilities (Minsky, 1988; Argyris and Schön, 1978; Lundgren, Säljö and Liberg, 2014).

Being able to develop one's professional competence to match the practical needs is a viable path to learning where the motivation is greatest among professionals (Ellström, 2011). In this light, the organizational and collective 
competence development measures alone are not sufficient (Schein, 1993; Schön, 1995).

Highlighting and being able to discuss, reflect, and learn more about the profession specific areas, both individually and collectively, is of great significance for professional development. Based on this reasoning, the learning process provides the professionals with their knowledge and sharpens their tools (Bruffee, 1993; Dillenbourg, 1999).

Organizations can thus be continuously improved through the professionals' own power. This process as a model for enhancing aspects of the professionals' competence can become an important part of their development, where professionals themselves shape and continuously revise their know-how in their work by relying on their own and their colleagues' competence and professionalism (Granberg and Ohlsson, 2016; Goldstein, 1981).

Responsibility issues are a part of the ethical competence in organization and a vital part in the work towards sustainable organization. Without ethical discussions at a deeper level, professionals deceive themselves and can deceive their customers. This leads to ethical stances being taken on unethical grounds (Oxenswärdh, 2011).

The balance between freedom on the one hand and responsibility on the other is upset, and the result is an organization like a stage with a nicely designed set but with a play that does not affect anyone. Organization development can be regarded as a force whereby the diversity, through refection and dialogue, results in new solutions that can be beneficial to everyone. Responsibility of the mission thus becomes a matter of debate among the professionals. Discussions intend to jointly interpret the responsibilities that the task contains (Granberg, 1996; Ohlsson, 1996; Wilhelmson, 1998; Döös and Wilhelmson, 2005; Granberg and Ohlsson, 2005; Oxenswärdh, 2011).

As the road to the mission and responsibility for understanding and accountability can be seen as a learning process, both in individually and collectively, emphasized the psychological and pedagogical dimension of the concepts of responsibility and change (Oxenswärdh, 2011). Regarding to mission and responsibility understanding, these can be seen as formed by learning processes. Factual knowledge base uses the familiarity of knowledge that in turn helps to shape and create understanding of the mission and the responsibility, within the change (ibid.).

The ideas, practices and methodologies how to handle requirements in an all changing world had been around for years when a group of computer industry experts come together in order to define general development values and principles for agile methodologies. The goal was to improve the software development process for companies around the world, and to give an alternative to the popular traditional heavyweight methodologies (Martin and Micah, 2006; Agile Alliance, 2018). These agile values and practices defined offer the ability 
to handle dynamic and non-deterministic changes in the environment that characterizes organisational changes.

The agile values stipulated highlights individual and interaction, working solutions, customer (stakeholders) collaboration, and being able to quickly and gracefully respond to change (Agile Alliance, 2018). These values are supplemented by the defined twelve principles (Agile Alliance, 2018) which form the guiding principles for the methodologies and that act as the characteristics for agile practices (Martin and Micah, 2006). These principles focus on bringing development into alignment with business and customer needs, a culture in which change is welcome, and the motivated skilled and engaged team members.

To appropriate knowledge and gain experience from agile methodologies and area of agility is essential for students to be well prepared for future labour market as indicated by the research and advisory company Gartner (2015).

This is due to the accelerating changes in not only related to organisations but to the general business and social environment that require dynamic and flexible way of working today and in the future.

In order to increase the motivation among students and to strengthen their ability to acquire effective agile project methods in the development of new products and services it is essential that the students are also actively working with these methods to solve a problem within a defined area (Devedzic' and Milenkovic, 2011; Zapater et. al., 2013). Problems that are used in the course should be linked to the involvement of students in solving their own identified problems. Like the student working with their fictive company in this course act as stimulus and provide the student with activities that offer them to develop a professional behaviour according to Boud and Feletti (1997). Therefor it was a necessity that the design of the course engaged the students and that the lectures are guiding and supporting them in their endeavour.

In summary, mission and responsibility understanding, are both processes formed by individual and collective learning. The process starts as an individual learning process. Subsequently, involved group reflections together with individual reflections create a collective learning. If students are given a possibility to clarify and discuss issues of change in collective, it also activates other processes of understanding their assignment and its responsibilities. These processes are important to be taken into consideration already while students are studying at the university.

\section{OBJECTIVES OF THE STUDY}

The course, Leadership for Change, (10 points) is divided into two main but interrelated sections: a project management section and the section related to change management. The project management section was planned in focusing 
on the agile methods that are common in both private and public sectors in organizations. It was further designed as a part of the course offering the tools for students in meeting challenges of creating an imaginary organization. The theme section, in turn, was highlighting important cornerstones of organizations' daily life in general and within organizational change, in special. Students were offered an opportunity in creating an organization of their own. In this section student really created a fictitious organization, working in small groups or teams, studying the following themes: the structure of the organization, human resources (HR), leadership, conflict management, change management and long-term development of the organization. The course consisted of different tasks carried out during the period 29 August 2017 - 13 January 2018.

Literature studies and inspirational lectures on six organizational themes were varied with knowledge of agile methods such as Scrum and Kanban within project management. After designing the foundation for their dream organization, the students were assigned small cases to work and solve with. The course was run both as a campus course and a separate course at distance. Students were working in small groups, some studying on campus and others at distance, during whole semester. Students then presented orally and through written reports their learning outcomes and processes continuously during the course. Evaluation of the processes were performed and documented by teachers as well as assessed several times during the course.

The project management section comprised of two phases. The first consists of six compulsory lectures on the philosophy and thoughts behind agile methods and a review of the two most common methods: Scrum and Kanban (Sutherland and Schwaber, 2017; Kniberg and Skrin, 2009).

The following phase consisted of applying these two methods as they performed their tasks related to the different themes, during the course. The first two thematic tasks were planned and implemented accordin $g$ to their normal way of performing this kind of activities however some of them used Kanban that the found suitable, while the two following had to be performed according to Kanban. The final two theme assignments were performed according to Scrum. In other words, before students begin their work on the different themes, they needed to plan how to implement these, and then follow up the changes in addition to analysing and evaluate the agile method used. Students were also expected to be active and involved in the planning, implementation and followup of these small agile projects that aimed at to generate the result for the second part of the course that was about leading change divided into different themes. This work should be documented on a regular basis (once or twice per week) to show how student managed to implement the methods. This documentation should form the basis of the mandatory follow-up meetings. For follow-up meetings should students appoint a chairman who chaired the meeting, convened and documented the meetings. An exam was conducted over the internet after the initial lectures in the initial phase of the course to validate that they had the fundamental knowledge required to carry out the themes. 
To sum up, the course consisted of two interconnected parts. The overall aim of this course design was to combine both structure and creativity in order to be able to create an organization corresponding to students' dreams. The course would also serve as a positive and creative ending on program studies, where the different study themes on quality technology, organizational theories and tools in project management would harmonize and create a whole that could enhance students' learning for current and future working life.

\section{STORY TELLING}

\section{Introduction}

Students' learning and teaching at the university level, is often focused on the theoretical knowledge. On campus Gotland, Bachelor Programme in Leadership, Quality and Improvement and Bachelor Programme in Quality Engineering and Management among others are offered. Both programs apply contacts with different external organizations and companies in different student tasks to provide insight into the practical activities. Many of these contacts contain problem solving of existing problems in these organizations. There are seldom opportunities for a more creative and imaginative approach, though. It is not often students have the opportunity to create something new and own using their theoretical knowledge, creativity and fantasy.

Students on these programmes at Uppsala university did have a need of strengthening their skills in project management and especially in using the agile methods. In this course we wanted to merge these two aspects: creativity and structure. We believe that these characteristics and tools are increasingly needed within organizational development in general and especially in change management. The course was given on bachelor level at Uppsala university, campus Gotland, within the division of Quality Technology. The course was conducted both as a campus course as well as a distance course online. The aim of the case is to give students an opportunity to practice acquired theoretical knowledge by offering them to create an organization of their dreams while working in small groups.

To enhance and deepen the students' learning process in the course, they are offered broadened knowledge of organizational aspects and cornerstones within change management, using a number of themes and agile methods.

Literature studies and inspirational lectures on six organizational themes were varied with knowledge of agile methods such as Scrum and Kanban within project management. After designing the foundation for their dream organization, the students were assigned small cases to work and solve with. Students were working in small groups, some studying on campus and others at distance, during whole semester. Students then presented orally and through written reports their learning outcomes and processes continuously during the course. Evaluation of 
the processes were performed and documented by teachers as well as assessed several times during the course.

The case study shows that course design can be an important inspirer and a bridge between theory and practice for the students. Course design seems to support students' learning processes due to evaluations of the course. Course design offers benefits of the collective learning, especially for distance students. It increases independence, understanding of one's mission and accountability for it. Students are given the opportunity to practice the theoretical knowledge in their education in a creative and inspiring way. Group processes sharpened their own tools and supported their ability to individual and collective learning.

Some of the parts of the course follow the structure of the so-called PPB, project and problem-based learning. The demands of studying using scientific articles as a course literature, also seemed to prepare students for a bachelor degree, which was planned to be a course, following this course.

This paper gives an example of how one university course can be designed in order to create deeper understanding for organizational change. The study makes a contribution to the discussion about learning within the university course as case study. Still the improvement of the course design is highly needed: there is a need of tightening up the relation between the theme section and the agile methods. Students were experienced them too much as two separate parts of the course.

\section{COURSE DESIGN AND ASSIGNMENTS}

\section{Campus and distance learning}

The students in the course comes from two separate programs in Engineering Sciences, Department of Quality Technology, Uppsala University, on campus Gotland: Program for Bachelor Programme in Leadership, Quality and Improvement and Bachelor Programme in Quality Engineering and Management. Both programs use to apply contacts with external companies and organizations at different student assignments for the purpose of expanding students' understanding of the practical work. Course, Leadership for Change was given both as a campus course and distance course. On campus were 19 students and at distance 36 students attending the course. Both course groups used the digital learning platform called Moodle as a support and meeting place in the course. Both E-classrooms were designed of course leader to give a structure for the course. Adobe Connect and Skype were used as communication channels on distance courser.

Homepages consisted of course information in the form of a schedule, syllabus, course literature, lecture material, places for submission of the course assignments and assessment, evaluations, open discussion forum and forum for the news. The website also contained several communication tools for the 
students. Course participants on campus come from both programs and were generally younger than distance students. The distance students again were all from the Bachelor Programme in Leadership, Quality and Improvement and were already working with side of their studies. They also were slightly older than campus students.

\section{The course design}

Students were offered live and distance online and recorded lectures. The course required team or group work that could be performed through physical or virtual meetings, such as via Adobe Connect, Skype, Face Time, Wiki, chat, conference call, etc. The group was free to choose the meeting form. The course also included group presentations of the various course assignments. These were done on the campus or via Adobe Connect. After each theme and group presentation, a written group report was to be submitted. In following figure course design in whole is presented, Fig. 1.

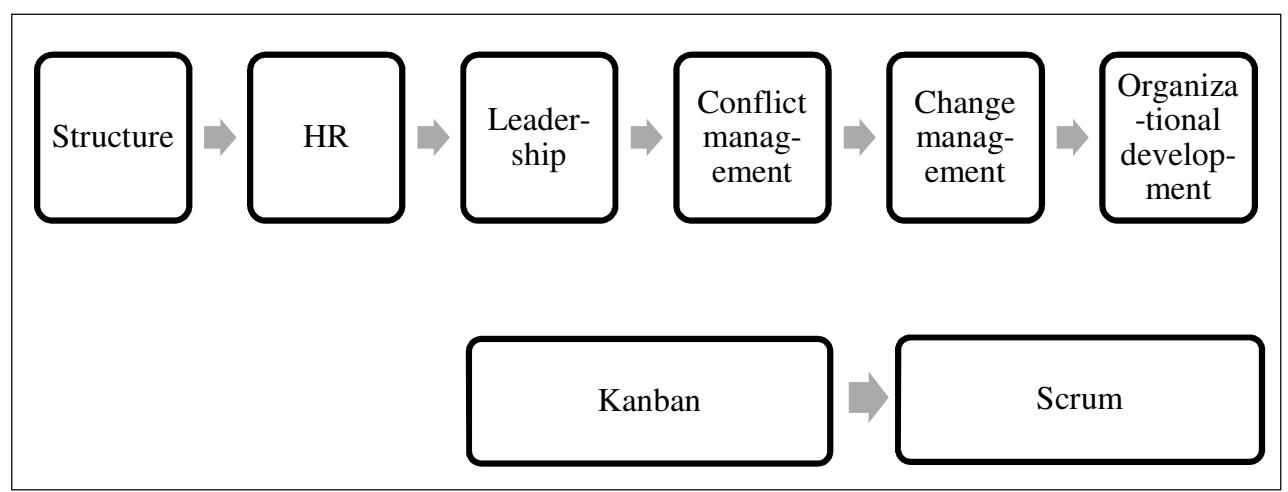

Figure 1 -Structure of the Course in Short Where the Themes and Their Relations Are Presented above and the Two Agile Methods Are included below

The course consisted of two interconnected sections: section related to change management and project management section. Six themes in the course can be seen as cornerstones and fundamental aspects of the life of any organization and important arenas in change management. In order to enlarge the tool box of project managers, agile methods, Kanban and Scrum were used as tools in the course. In the following the schedule of the course is presented.

In the Tab. 1 the overall schedule of the course is presented. Themes in the course were varied by lectures and workshops in agile methods in order to support students' learning outcomes on organizational change and offer structure on studies with own imaginary organizations. The design followed the structure where themes were first presented by theoretical lectures, often performed by guest lectures. After that students got a task of designing the theme in their own organizations, which was then presented in group. A written report was finalizing all themes. 


\section{Agile methods}

The agile values and principles together with two agile methods that were given in number lectures/seminars to all students. The campus students were offered the opportunity to practice the two methods using a minor exercise, something that could not be offered over internet to distant students. For two themes (leadership and conflict management) they used the agile method Kanban and in the following two themes (change management and organizational development) they practiced the method Scrum. The student groups submit their progress using established practices within the two agile methods so that they could be with provided appropriate scaffolding to facilitate their learning. The students had to write a final report after exercising each of the two methods.

They presented in detail how they had executed the method and discussed their thoughts about how the work had progressed and submitted their subjective opinions regarding the two methods. These reports were presented and discussed with the lecture in a follow-up meeting.

Table 1 - Course Schedule

\begin{tabular}{|l|l|l|l|}
\hline \multicolumn{1}{|c|}{ Themes } & When? & \multicolumn{1}{|c|}{ What? } & \multicolumn{1}{c|}{ How? } \\
\hline Introduction & w 35 & Grouping, task sharing & $\begin{array}{l}\text { Introduction lecture } \\
\text { seminar }\end{array}$ \\
\hline $\begin{array}{l}\text { Project } \\
\text { management }\end{array}$ & w 36 & 2 half days & Lecture and seminar \\
\hline $\begin{array}{l}\text { Project } \\
\text { management }\end{array}$ & w 37 & 2 half days & Lecture and seminar \\
\hline $\begin{array}{l}\text { Project } \\
\text { management }\end{array}$ & w 38 & 2 hours examination & Online examination \\
\hline $\begin{array}{l}\text { Structure } \\
\text { HR }\end{array}$ & w 39 & $\begin{array}{l}\text { Form/type structure, vision } \\
\text { production/service management } \\
\text { system, quality system } \\
\text { Who works here? What do they have } \\
\text { for professional competencies? What } \\
\text { does organizational culture look like? } \\
\text { Basic values? Competence? }\end{array}$ & $\begin{array}{l}\text { Presentations of } \\
\text { organizations }\end{array}$ \\
\hline organization must be \\
\hline submitted in writing
\end{tabular}




\begin{tabular}{|c|c|c|c|}
\hline Themes & When? & What? & How? \\
\hline $\begin{array}{l}\text { Leadership in } \\
\text { practice }\end{array}$ & w 42 & $\begin{array}{l}\text { Management / leaders. Leader profiles } \\
\text { and responsibilities. }\end{array}$ & $\begin{array}{l}\text { Presentations in groups, } \\
\text { submitted group report } \\
\text { Discussions }\end{array}$ \\
\hline $\begin{array}{l}\text { Conflict } \\
\text { management }\end{array}$ & w 43 & $\begin{array}{l}\text { Inspirational lecture of Conflict } \\
\text { management, guest lecturer } \\
\text { Project part: According to Kanban }\end{array}$ & $\begin{array}{l}\text { Lecture } \\
\text { Seminar } \\
\text { Small cases are handled } \\
\text { out }\end{array}$ \\
\hline $\begin{array}{l}\text { Conflicts in } \\
\text { practice }\end{array}$ & w 44 & Suggest solutions for cases & $\begin{array}{l}\text { Report at least three } \\
\text { solutions. } \\
\text { Submit written report }\end{array}$ \\
\hline $\begin{array}{l}\text { Leadership \& } \\
\text { Conflict } \\
\text { management }\end{array}$ & w 45 & $\begin{array}{l}\text { Write and submit final report Kanban } \\
\text { Follow-up meeting to present and } \\
\text { discuss experience using Kanban }\end{array}$ & $\begin{array}{l}\text { Report Kanban } \\
\text { Presentation Kanban }\end{array}$ \\
\hline $\begin{array}{l}\text { Change } \\
\text { Management }\end{array}$ & w 46 & $\begin{array}{l}\text { Guest lecturer } \\
\text { Project part: According to Scrum }\end{array}$ & $\begin{array}{l}\text { Seminar + discussions in } \\
\text { groups } \\
\text { Write and submit report, } \\
\text { follow-up meeting }\end{array}$ \\
\hline $\begin{array}{l}\text { Change } \\
\text { Management in } \\
\text { practice }\end{array}$ & w 47 & $\begin{array}{l}\text { Assigned changes in your organization } \\
\text { are to be presented, what do you do, } \\
\text { plan, act, manage! Suggest solutions }\end{array}$ & $\begin{array}{l}\text { Report at least three } \\
\text { solutions } \\
\text { Presentations and } \\
\text { discussions }\end{array}$ \\
\hline $\begin{array}{l}\text { Organization } \\
\text { development }\end{array}$ & w 48 & $\begin{array}{l}\text { Guest lecturer. } \\
\text { Project part: According to Scrum }\end{array}$ & Seminar + workshop \\
\hline $\begin{array}{l}\text { Organization } \\
\text { development in } \\
\text { practice }\end{array}$ & w 49 & $\begin{array}{l}\text { Design for continuous development } \\
\text { plan for organization } \\
\text { Write and submit final report Scrum } \\
\text { Follow-up meeting to present and } \\
\text { discuss experience using Scrum }\end{array}$ & $\begin{array}{l}\text { Presentations } \\
\text { Report Scrum } \\
\text { Presentation Scrum }\end{array}$ \\
\hline $\begin{array}{l}\text { Presentation of } \\
\text { the organization } \\
\text { on the } \\
\text { recruitment fair }\end{array}$ & w 50 & $\begin{array}{l}\text { Organizations are to be presented in } \\
\text { whole / at the fictive recruitment fair. } \\
\text { Write and submit report and attend } \\
\text { into follow-up meeting. }\end{array}$ & $\begin{array}{l}\text { Presentations in groups, } \\
\text { discussions and oral } \\
\text { evaluation of the course }\end{array}$ \\
\hline
\end{tabular}

\section{Assignments}

\section{Logbooks - throughout the course}

Students were expected to write logbook reflections throughout the autumn. They were supposed to individually document the group's work processes throughout the course. This logbook should then be highlighted in the final written assignment and be included in it as an attachment. The logbook notes described thoughts on the different processes about the course and how these could be linked to the course literature and the chosen scientific articles. Students were encouraged to write down after each course session their own thoughts about the processes they had observed in their group during the group work. 
They were asked: What kind of group processes can you distinguish? (e.g. power distribution, culture, conflict, consensus, compromise, decision, reward, group think etc.?)

\section{1st Assignments (a-c) in Project management section}

- Written exam - Friday 22/9 to Sunday 24/9. (Score: 3, 4 and 5);

- Perform the theme work according to the predetermined agile method (Kanban). Describe the planning, implementation and results of a project report and active participation in follow-up meeting (mandatory) where the group reports were verbally;

- Perform the theme work according to the predetermined agile method (Scrum). Describe the planning, implementation and results of a project report and active participation in follow-up meeting (mandatory) where the group reports presented verbally about how they worked, problems and advantages and disadvantages.

\section{2nd Assignments in theme section}

- Oral group reports and written reports over the different themes (six);

- Containing descriptions of how students had applied the theme in their fictitious organizations. They should also have references to the course literature and to at least three scientific articles per theme;

- Rating: G / U;

- Final report: Written assignment - final exam (3 hp) Grading scale: U, $3,4,5$;

- Deadline: 13/1 2018.

This individual written and final assignment aimed at to summarize the different parts of the course. Students was to present their fictional organization based on the different themes of the course. The analysis of themes should contain a theoretical review of the choices that the group made when creating their organization. They also should analyse and interpret the processes that they had undergone during the work with the organization.

The form of the assignment was as follows: the work was to contain 8 chapters: Introduction, Organization Structure, HR, Leadership, Change, Conflicts, Organization Development and Discussion. Each chapter (except 1 and 8) should follow the draft: results - analysis - reflection.

In Chapter 1, students should present the organization by portraying the organization in its entirety in order to provide the best possible image of it. In the final chapter, then summarize these different chapters and discuss the group process and their individual learning process by adopting a more objective approach. Additionally, they should use quality tools where needed. In the analysis they should describe the structure by using theories and refer to the 
literature. They also were expected to describe how they had used their quality tools. Finally, in the reflection section, students should add their own thoughts about the processes involved (logbook notes as a support). Work scope: about 15-20 pages, reference system Harvard Anglia.

The course consisted of two interconnected parts. The overall aim of this course design was to combine both structure and creativity in order to be able to create an organization of students' dreams.

The course would also serve as a positive and creative finish on program studies where the different study themes on quality technology, organizational theories sand tools in project management would harmonize and create a whole that could enhance students' learning for current working life. Processes of learning by working in teams in this project seem to strengthen students' knowledge of organizational change in many ways. Students could in better way combine the theoretical knowledge of processes within organizational changes with the practical being active change mangers themselves and using the agile methods, Kanban and Scrum. They witnessed, through evaluations and different tasks, how even processes of understanding the mission and its responsibilities where highlighted by the course design.

Still an improvement of the course design is highly needed: there is a need of tightening up the relation between the theme section and the agile methods. Students were often experiencing them as two separate parts of the course. In the following section a solution for the case study is discussed.

\section{Solution of the case study}

One possible solution to the course can be represented by a change in the course design. The new design was planned to include better link between theory and practice but also encourage students to use more of their creativeness and problem-solving skills. In addition, it was thought that, with this new course design, students would better be able to repeat the various aspects of the entire program and gain experience and insight onto how agile methods can be used especially in change management, prior to graduation.

The course was evaluated continuously and orally during the course by formative evaluation and in the end of the course by summative evaluation. Evaluation results show following results: The summative evaluation was answered by $32 \%$ of the campus students $(6 / 19)$ and by $28 \%$ or $(10 / 36)$ of the distance students. The general appreciation of the course was very positive. Course design was experienced by the majority as inspirational and useful for the future's working life. Weaknesses of the course, experienced by students, were mostly connected to project section and/or to the connection between these two sections of the course. Teachers were not cooperating enough with each other, the sections were experienced as two separate parts instead of properly interconnected, as they were expected to do by students. The best part of the course has been the course design and problem solving in groups. The students have practiced the theoretical 
knowledge from the entire education through the six themes. In general students found it stimulated and it supported them to collaborate in a constructive way. Students at the distance course experienced working in groups even more satisfactory. This because they often are not offered many group activities online.

Improvement suggestions from the students can be summarizes as follows: Communication between teachers has to be improved. Clarity in the course design, better structure for the e-classroom is proposed. Minimize a number of course assignments. Evaluations and student statements show though that course design, the completed change in it, is experienced by majority of the students as interesting and something what can increase their learning outcome in the programme. But at the same time there are shortcomings which are to be taken seriously. The course structure will be revised to better meet student needs and further enhance learning in the course.

\section{Plan for future improvements of the course}

The following improvement are to be included in the course design:

- A closer cooperation between the teachers in the course, in order to better weave the two course moments into a whole according the principle of constructive alignment.

- Reduce the number of course assignments in order to give more time and space for the creative problem solving in the course.

- The constructive alignment can be performed on different levels: on teaching/learning level, on task/assignment level, on assessment level and on evaluation level.

\section{Summary}

It is obvious that the students have enjoyed this new course design and that it has supported their learning outcomes. It has further helped to reduce the gap between theory and practice as well as prepare students for collective learning in teams at future work. However, after course evaluation, it can still be noted that the course design has some shortcomings. The students have experienced that the course parts are more or less separate.

This can be seen as trying to put together two separate scientific disciplines in one course. The project part has been experienced by the students as something which belongs more into the natural sciences approach of solving problems. In addition, this includes some kind of instrumentalism, more technical and solution-oriented views on change management. On the other hand, the students felt that the theme part offered more understanding-oriented solutions, creativity and imagination.

Courses in Quality Technology are characterized by different scientific views: on the one hand, technical, numerical and static tools and models are highlighted for problem solving; on the other hand, people, their activities and members of 
organizations are focusing on the subjective approaches, offered by humanism. Specially in order to cope with changes in the organizations, it would be an asset to reconcile these approaches for more successful work.

In order to bridge the gap between these two different scientific perspectives, further didactic measures are needed. First and foremost, the teachers in the course should see each other's parts as equivalent and something that complements each other in a good way. In practice, the different parts of the course should not appear as two separate parts but something intertwined in the different didactic parts of the course. Perhaps the course could be performed simultaneously on both parts. The course's tasks could contain both parts at the same time and assessment should also be based on the same material. It will also be possible to conduct joint evaluations on the course.

\section{Procedures for applying in the classroom}

In the following the procedures in the classroom theme by theme are presented. This didactic plan includes processes of teaching and learning as well as objectives or goals for learning outcomes.

Theme studies are designed as a support for students creating an imaginary organization. During the first five weeks the students shall be familiarized to agile methodologies and the two methods that will be introduced in the course as depicted in Fig. 2.

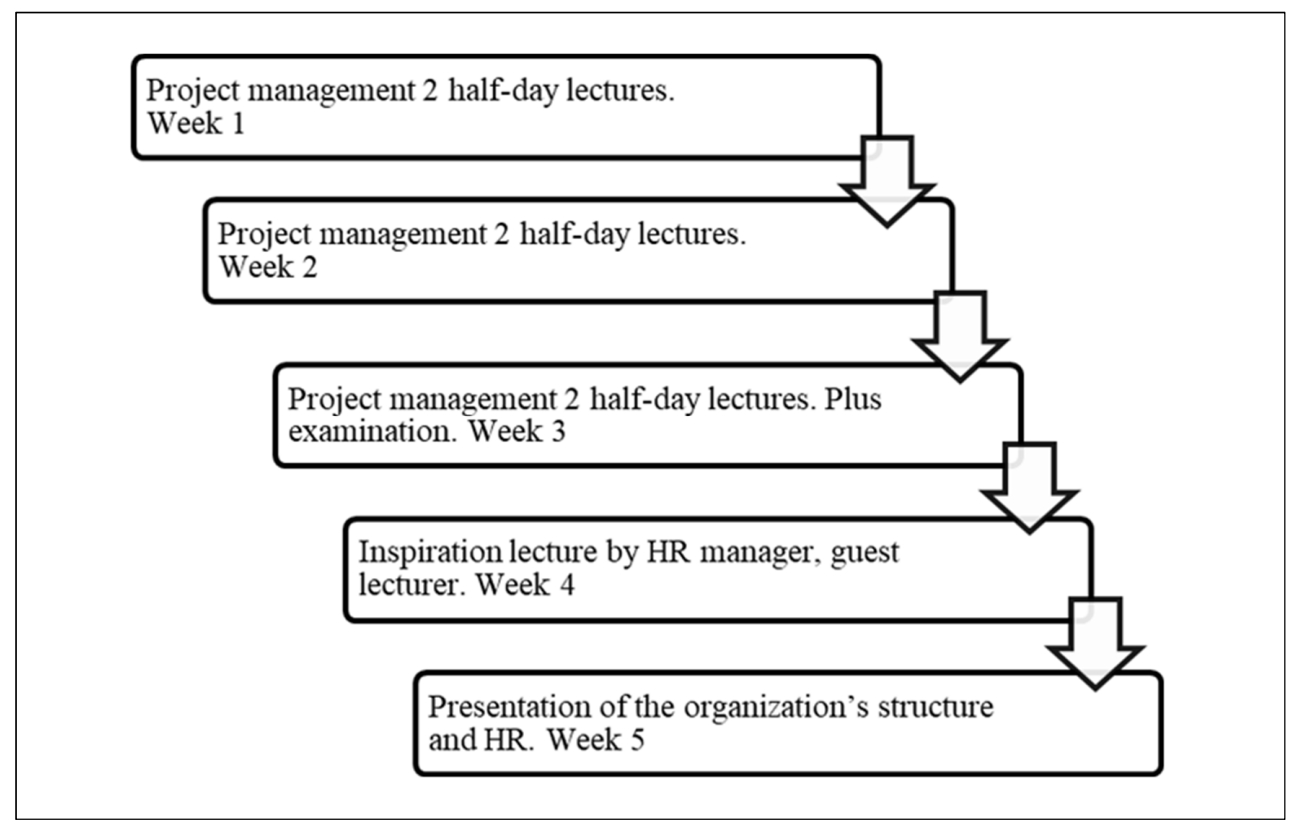

Figure 2 - The First Two Themes, in the Course, Together with Introduction to Agile Methodologies, Kanban and Scrum Are to Be Presented 


\section{Themes 1 and 2: structure and human resource}

Goals for the theme structure and HR: Students should start creating the structure of their dream organization in small groups including the vision, production/service/size etc. They should add design of management and quality systems in the organization. Describing who works in the organization? What do they have for professional competencies? How does their organizional culture look like? What are their basic values? How is HR organized and managed? The base processes that exist in the organization related to resource staff? An oral presentation over their dream organization's structure and HR are required. A written report is to be submitted with references to the course literature and three scientific articles of their choice.

Assessment criteria: General assessment criteria for both oral group presentations and written reports are: The theme has been adequately addressed through group presentations and the written report. The group members have shared the work in the group and are actively participating in the presentations. They also participate in discussions and reflections over the their own but even other groups presentations. In the written reports, theory of the subject should be used in the form of course literature and the chosen articles.

The theme should be studied in deeper perspectives than in previous courses by making relevant theoretical references and connections into their organisation building. Both tasks are graded as Approved - Not approved.

Project content: It is left up to the studnet to choose how they would like to structure their way of working.

\section{Themes 3: Leadership}

Leadership is to presented by repeating previous gained knowlegde in the programme. Leadership History and today's leadership influences are to be discussed. Inspiration lecture should take up leaders and mangers as well as project leaders daily work in practice. Guest lecturer is preferred.

Students work in small groups: Organization's management system is presented in more detail. Leaders' profiles, responsibilities and powers, the work of the board, leadership views and visions, leadership strategies and practical work are lit.

Tasks: Students are to present the organization's management system in groups both orally and with the written report.

Assessment criteria: Same as above.

Project content: During the theme the agile method Kanban will be introduced. The method is extended with a practice normally associated with the other agile method, Scrum, namely the time-boxing practice. This is done to provide adequate scaffolding for students om regular basis. 
Project Assessment criteria: The student groups have to submit their progress report weekly using established practices within the method, e.g. via cumulative flow diagram and Kanban-board. It is a formative assessment aimed at give the students support so that they will learn the method and its associated tools and practices.

\section{Themes 4: Conflict Management}

Inspiration lecture takes up the theoretical aspect of conflict management and presents some models and strategies in coping the conflict in practice. Students are then given small cases for each group to be discussed and solved. Conflicts are constructed suiting every organization individually. At least three solutions must be presented. A written report over the solutions are to be submitted.

Assessment criteria: Same as above.

Project content: During the theme the agile method Kanban with its extended practice will be used to its fully extent.

Project Assessment criteria: The students shall continuously report their progress using established practices. In addition they have to write a final methodreport, including planning and follow-up of the themes and students' subjective opinions regarding the method.

\section{Themes 5: Change management}

Change management. Inspiration lecture over the theme, change management, should be given in order to update the area of knowledge. The cases of change distribute for the students to be solved in groups. Students are reporting at least three solution proposals, both orally and written.

Assessment criteria: Same as above.

Project content: During the theme the agile method Scrum will be introduced to structure the students work with the theme.

Project Assessment criteria: The student groups have to submit their progress report twice a week using established practices within the method, e.g. via burn down chart and Scrum-board. It is a formative assessment aimed at give the students support so that they will learn the method and its associated tools and practices.

\section{Themes 6: Organisational Development}

Organisational Development it introduced through an inspiration lecture. The aim of the theme is to draw students' attention to the long-term process of developing their organization. Organizational learning for continued development becomes important in order to see obstacles but also opportunities in their own organizations. 
Task: Students are to be attending a fictive recruitment fair. Their task is to promote their organization to attract new competencies. They shall then present their organizations briefly by summarizing the chosen parts of it.

Assessment criteria: Same as above.

Project content: During the theme the agile method Scrum will be used to its fully extent.

Project assessment: The will continuously report their progress twice a week using established practices. In addition they have to write a final methodreport, including planning and follow-up of the themes and students' subjective opinions regarding the method

Final grading: The grades from written agile method exam and the final written assignment for the themes was weighted together to form the final grade $(30 \%$ project and $70 \%$ change management). Grading scale: $\mathrm{U}, 3,4,5$.

\section{SUMMARY}

This case study is based on the introduction of new university course design for teaching change management to students however it is also suitable for professionals at various positions to learn more about the subject. The course was a mandatory part of the curriculum for last year bachelor students in two programs, Bachelor Programme in Leadership, Quality and Improvement and Bachelor Programme in Quality Engineering and Management, at Uppsala University Campus Gotland. The course was given both as a campus course as well as distance course during autumn 2017.

The course was designed in such a way to offer the students the possibilities to use their creativity and their accrued knowledge from previous courses in their bachelor studies to get a deeper understanding of organizations in general and change management in particular. The way to achieve this was through letting them in a structured manor take part of scientific literature and inspiration lectures given by experts in their fields. The various student groups created their own fictive organization that was subjected to exogenous stimulus that the organization had to handle in an appropriate way this to emulate change management situations.

Structure to their creativity was brought by introducing them to agile methods that offer a structured however also a dynamic and flexible framework for designing products and services. These characteristics make them suitable in a dynamic environment where successful organization is one that adapts to change, anticipate future needs and aim for high added value in the long term.

The basic ideas behind the design of the course and the foundations were 1) important to develop activities within university course about organizational context in order to increase students understanding of the goals for more 
sustainable practice 2) individually and collectively learning progression, emphasizing the psychological and pedagogical dimension of the concepts of responsibility and change 3) integration of two separate scientific disciplines (project and change management) 4) the importance of actively working with agile methods to solve a problem within a defined area to strengthen their ability to acquire understanding of the methods.

Formative evaluation is recommended orally and continuously during the course to address various topics and in the end of the course by summative evaluation. The summative evaluation was answered by $32 \%$ of the campus students $(6 / 19)$ and by $28 \%$ or $(10 / 36)$ of the distance students. The general appreciation of the course was very positive.

Course design was experienced by the majority as inspirational and useful for the future's working life. They were in general appreciative of being able to practice their earlier acquired knowledge and to the collaborative learning in their groups something that was elaborated by using the agile methods based on team work and thereby support this kind of learning. The main weakness was the integration of the two disciplines leading to the feeling that the course consisted of two courses instead of one integrated course. The evaluation will lead to enhanced collaboration and coordination between the two disciplines especially in regard to the theme phase where the themes are executed using the agile methods. It means that common report structure is recommended to implement instead of to separate structures one for each discipline (project and change management). Finally, the number of assignments should be reduced so that students will be able to elaborate their knowledge.

\section{REFERENCES}

Agile Alliance, 2018. Agile Alliance. The alliance. Available at: $<$ http://www.agilealliance.org/the-alliance/> [Accessed 5 April 2018].

Argyris, C. and Schön, D.A., 1978. Organizational learning: A theory of action perspective. Boston: Addison \& Wesley Pub, Co.

Boud, D. and Feletti, G., 1997. The challenge of Problem Based learning. London: Kogan Page.

Bruffee, K.A., 1993. Collaborative Learning: Higher Education, Interdependence, and the Authority of Knowledge. Baltimore, Md.: Johns Hopkins University Press.

Devedzic', V. and Milenkovic, S.R., 2011. Teaching Agile Software Development: A Case Stud. IEEE Transactions on Education, 54(2), pp.273-283. http://dx.doi.org/10.1109/TE.2010.205210.

Dillenbourg, P., 1999. Collaborative Learning: Cognitive and Computational Approaches, Advances in Learning and Instruction Series, New York: Elsevier Science. 
Döös, M. and Wilhelmson, L., 2005. Kollektivt lärande. Om betydelsen av interaktion i handling och gemensam handlingsarena. Pedagogisk forskning i Sverige, 10(3/4), pp.209-226.

Ellström, P.-E., 2011. Informal learning at work: Conditions, processes and logics, In: M. Malloch, L. Cairns, K. Evans and B. O'Connor, eds. 2011. eSAGE Handbook of Workplace Learning. London: Sage Publications. pp.105-119.

Foley, K.J. and Zahner, T., 2009. Creating and Managing the Sustainable Organization: The Stakeholder Way. Sydney: SAI Global.

Forslund, M., 2013. Organization and Management. Stockholm: Liber.

Gartner, 2015. 2016 Planning Guide Overview: Set the Pace With Agility, Design and Innovation. [online] Available at: $<$ https://www.gartner.com/doc/3142818?refval=\&pcp=mpe\#a-14327807> [Accessed 5 April 2018].

Goldstein, H., 1981. Social Learning and Change: A Cognitive Approach to Human Services. Columbia, SC: University of South Carolina Press.

Granberg, O. and Ohlsson, J. eds., 2016. Kollektivt lärande i arbetslivet. Lund: Studentlitteratur.

Granberg, O. and Ohlsson, J., 2005. Kollektivt lärande i team. Pedagogisk forskning i Sverige, 10(3/4), pp.227-243.

Granberg, O., 1996. Learning in organizations. Professional practitioners' strategies for organizational change. Stockholm University.

Hallencreutz, J., 2012. Under the skin of change - meanings, models and management. Doctoral Thesis. Luleå, Sweden: Luleå University of Technology, Department of Business Administration, Technology and Social Sciences, Division of Quality Management.

Illeris, K. 2007. Learning. Lund: Studentlitteratur.

Kniberg, H. and Skrin, M., 2009. Kanban and Scrum making the most of both. [pdf] United State of America: C4Media Inc. Available at: $<$ http://www.agileinnovation.eu/wordpress/wpcontent/uploads/2010/09/KanbanAndScrum_MakingTheMostOfBoth.pdf> [Accessed 25 March 2019].

Kotter, J., 2012. Leading Change. Boston, MA: Harvard Business Review Press.

Kotter, J., 2014. Accelerate: Building Strategic Agility for a Faster-moving World. Boston, MA: Harvard Business Review Press.

Lundgren, U., Säljö, R. and Liberg, C., 2014. Lärande, skola, bildning: grundbok för lärare. Stockholm: Natur \& kultur.

Martin, R.C. and Micah, M., 2006. Agile principles, patterns, and practices in C\#. Massachusetts: Prentice Hall.

Minsky, M., 1988. Society of Mind. New York: Simon and Schuster. 
Ohlsson, J., 1996. Kollektivt lärande: lärande $i$ arbetsgrupper inom barnomsorgen $=$ Collective learning: learning within workgroups at daycare and leisure centres for children. Stockholm: Stockholms universitet.

Oxenswärdh, A., 2011. Responsibilities in School Improvement. Doctoral thesis. Stockholm: Stockholm University.

Oxenswärdh, A., 2017. Student's learning processes for sustainable knowledge. Millenium, 2(4), pp.33-43.

Schein, E.H., 1993. On dialogue, culture, and organizational learning. Organizational Dynamics, 22(2), pp.40-51. https://doi.org/10.1016/00902616(93)90052-3.

Schön, D.A., 1995. Reflective practitioner: how professionals think in action. Melbourne: Arena. $\square$

Sutherland, J. and Scwaber, K., 2017. The Scrum Guide: The definitive guide to scrum: The rules of the game. [online] Available at: $<$ https://www.scrumguides.org/> [Accessed 04 July 2018].

Taylor, S., 1999. Better Learning through Better Thinking: Developing Students' Metacognitive Abilities. Journal of College Reading and Learning, 30(1), pp.3445. https://doi.org/10.1080/10790195.1999.10850084.

Wilhelmson, L., 1998. Learning dialogue: Discourse patterns, perspective change and learning in small group conversation. Doctoral thesis. Solna, Sweden: Stockholm University, Department of Education.

Zapater, M., Malagón, P., de Goyeneche, J-M. and Moya, J.M., 2013. ProjectBased Learning and Agile Methodologies in Electronic Courses: Effect of Student Population and Open Issues. Electronics, 17(2), pp.82-87.

\section{ABOUT AUTHORS}

Anette Oxenswardh - PhD. Senior Lecturer, Uppsala University/Campus, Gotland, Department of Engineering Sciences, Quality Sciences, Sweden. E-mail: anette.oxenswardh@angstrom.uu.se. Author's ORCID: orcid.org/00000001-9690-2620.

Per-Arne Forsberg - Licentiate of Engineering, Lecturer, Uppsala University /CampusGotland, Department of Engineering Sciences, Quality Sciences, Sweden. E-mail: per-arne.forsberg@angstrom.uu.se. Author's ORCID: orcid.org/0000-0001-7727-354X.

(C) 2019 by the authors. Submitted for possible open access publication under the terms and conditions of the Creative Commons Attribution (CC-BY) license (http://creativecommons.org/licenses/by/4.0/). 